\title{
Challenges in Community-Research Relationships: Learning from Natural Science in Nunavut
}

\author{
SHARI GEARHEARD ${ }^{1}$ and JAMAL SHIRLEY ${ }^{2}$
}

(Received 22 December 2005; accepted in revised form 31 August 2006)

\begin{abstract}
The context and conduct of Arctic research are changing. In Nunavut, funding agencies, licensing bodies, and new regulatory agencies established under the Nunavut Land Claims Agreement require researchers to engage and consult with Inuit communities during all phases of research, to provide local training and other benefits, and to communicate project results effectively. Researchers are also increasingly expected to incorporate traditional knowledge into their work and to design studies that are relevant to local interests and needs. In this paper, we explore the challenges that researchers and communities experience in meeting these requirements by reviewing case studies of three natural science projects in Nunavut. Together, these projects exemplify both success and failure in negotiating research relationships. The case studies highlight three principal sources of researcher-community conflict: 1) debate surrounding acceptable impacts of research and the nature and extent of local benefits that research projects can and should provide; 2) uncertainty over who has the power and authority to dictate terms and conditions under which projects should be licensed; and 3) the appropriate research methodology and design to balance local expectations and research needs. The Nunavut research licensing process under the Scientists Act is an important opportunity for communities, scientists, and regulatory agencies to negotiate power relationships. However, the standards and procedures used to evaluate research impact remain unclear, as does the role of communities in the decision-making process for research licensing. The case studies also demonstrate the critical role of trust and rapport, forged through early and frequent communication, efforts to provide local training, and opportunities for community members to observe, participate in, and derive employment from project activities. Clarifying research policies in Nunavut is one step to improving relations between scientists and communities. In addition, steps need to be taken at both policy and project levels to train researchers, educate funding programs, mobilize institutions, and empower communities, thus strengthening the capacity of all stakeholders in northern research.
\end{abstract}

Key words: research methods, participatory research, science, Nunavut, Inuit, communities, traditional knowledge

RÉSUMÉ. Le contexte et la réalisation des travaux de recherche dans l'Arctique sont en pleine évolution. Au Nunavut, les organismes de financement, les organismes de délivrance de permis et de nouveaux organismes réglementaires mis sur pied en vertu de l'Entente sur la revendication territoriale du Nunavut exigent des chercheurs qu'ils recourent aux services des collectivités inuites et les consultent à toutes les étapes des travaux de recherche, qu'ils assurent la formation des personnes auxquelles ils font affaire et leurs fournissent d'autres avantages, puis qu'ils communiquent bien les résultats des projets réalisés. Par ailleurs, on s'attend de plus en plus à ce que les chercheurs intègrent les connaissances traditionnelles à leur travail et conçoivent des études qui se rapportent aux intérêts et aux besoins cernés dans la région. Dans ce document, nous nous penchons sur les défis que doivent relever les chercheurs et les collectivités pour répondre à ces exigences en nous appuyant sur les études de cas de trois projets en sciences naturelles réalisés au Nunavut. Ensemble, ces projets exemplifient tant la réussite que l'échec en matière de négociation de relations de recherche. Ces études de cas mettent en évidence trois sources principales de conflits entre les chercheurs et la collectivité : 1) le débat concernant les incidences acceptables de la recherche de même que la nature et l'étendue des avantages ressentis à l'échelle locale découlant ou susceptibles de découler des projets de recherche; 2) l'incertitude quant à savoir à qui revient le pouvoir et l'autorité de dicter les modalités en vertu desquelles les projets de recherche devraient se voir accorder un permis; et 3) le caractère adéquat de la méthodologie et de la conception de la recherche en matière d'équilibre des attentes des gens de la région et des besoins de la recherche. En vertu de la Loi sur les scientifiques, le processus de délivrance des permis de recherche au Nunavut constitue une manière importante pour les collectivités, les scientifiques et les organismes réglementaires de négocier des rapports de force. Cependant, les normes et les méthodes servant à évaluer les incidences des projets de recherche ne sont toujours pas claires, ce qui est également le cas du rôle des collectivités dans le processus de prise de décisions en matière de délivrance des permis de recherche. Les études de cas font également ressortir le rôle critique de la confiance et des relations, ceux-ci étant le résultat de communications qui se font fréquemment et sans tarder, d'efforts pour fournir de la formation à l'échelle locale et d'occasions, pour les membres de la collectivité, d'observer ce qui se passe, de participer et de se trouver du travail dans le cadre des activités de recherche. Au Nunavut, la clarification des politiques de recherche constitue une manière d'améliorer les relations entre les scientifiques et les collectivités. De plus, des mesures doivent

1 Cooperative Institute for Research in Environmental Sciences (CIRES), University of Colorado at Boulder; address: P.O. Box 241, Clyde River, Nunavut X0A 0E0, Canada; sharig@qiniq.com

${ }^{2}$ Nunavut Research Institute, P.O. Box 1720, Iqaluit, Nunavut X0A 0H0, Canada; jshirley@ nac.nu.ca

(C) The Arctic Institute of North America 
être prises sur le plan des politiques et des projets pour former les chercheurs, sensibiliser les responsables des programmes de financement, mobiliser les établissements et habiliter les collectivités et ce, afin de renforcer la capacité de tous les intervenants touchés par les travaux de recherche dans le Nord.

Mots clés : méthodes de recherche, recherche participative, science, Nunavut, Inuit, collectivités, connaissances traditionnelles

Traduit pour la revue Arctic par Nicole Giguère.

\section{INTRODUCTION}

In some parts of the Canadian Arctic, local Inuit refer to researchers as "siksiks" - 'ground squirrels' in Inuktitut. For many northern communities, researchers and siksiks seem to share similar characteristics: they appear suddenly, usually in the summer months, scurry around on the tundra doing whoknows-what, and then disappear just as quickly without anyone's knowing exactly what they were up to. Sometimes siksik is used in a friendly, joking manner. Other times the nickname expresses negative feelings toward researchers: a mistrust that stems from a history of non-communication, miscommunication, and misunderstanding.

The term "natural science" as used in this paper refers to all sciences outside the social and health sciences that do not normally engage local communities in study design or data collection or have local people in mind as an audience for their results. This does not imply that no natural science projects work with communities; only that we are examining the ones that do not. Projects that investigate topics in geomorphology, atmospheric chemistry, paleoclimatology, and so on are often located, by necessity, at remote field sites far from communities, which makes contact between scientists and local residents more difficult, if it occurs at all. Moreover, natural science often seeks to discover or explain processes and phenomena that researchers and community members alike might consider outside the domain of local knowledge (e.g., geomagnetic phenomena, fate and behaviour of atmospheric contaminants, and sedimentology). To participate in such scientific research projects, local community members need training and qualifications that northern agencies and scientific researchers (and perhaps community residents) view as more rigorous than those for biological projects such as wildlife studies that use hunters' observations or for health and social science projects.

Like other researchers, natural scientists are carrying out their studies in a venue that is very different from the Arctic of even a decade ago (Korsmo and Graham, 2002). Institutional and political structures and policies created as part of the comprehensive land-claim agreements in the North have greatly changed the context for all research and research relationships. Research and licensing guidelines (e.g., NRI and ITC, 1998) call for communication and consultation between researchers and communities, and changing research methods and new attitudes toward research at the local and territorial levels also contribute to a new working atmosphere. In the last decade, an emphasis on local and traditional knowledge and participatory research has helped create a paradigm shift: scientific studies can no longer take place in the Canadian Arctic without some communication and consultation with a local community. This shift has also raised local awareness of research, and communities and indigenous organizations are increasingly taking an interest in (and control of) research and demanding more local involvement and opportunities from research programs. Some funding agencies have responded to the shift as well by setting requirements for outreach and interaction with local people. As a result, Arctic natural research scientists, who for years did not have to consider issues of community involvement, are now finding themselves increasingly challenged by the need to seek local consultation and approval, explain the rationale and potential local relevance of their projects, and include community participation and communication in their work.

This paper examines relationships between researchers and Inuit communities in Nunavut, Canada. We focus on the challenges unique to natural sciences, basing our discussion on recent experiences of natural science researchers and Nunavut communities who negotiated over a research project. We review three case studies: two cases in which researcher-community negotiations initiated as part of the mandatory licensing process failed to satisfy one or both parties, and one case in which successful agreements were reached. All three cases provide perspectives from researchers as well as communities, creating the basis for a discussion that explores the complex interaction of social, economic, and political factors that determines the success or failure of researcher-community relations. We focus on identifying some basic measures that scientists might consider to engage communities more effectively in their studies, as well as project- and policylevel changes that might be implemented to improve research relationships. We hope our work will prove useful for researchers and communities alike as they strive to develop more productive, equitable relationships that better reflect and support their respective needs, concerns, and aspirations.

\section{NATURAL SCIENCE RESEARCH IN NUNAVUT}

Each northern region faces unique challenges with respect to local engagement in research. The standards for, concerns about, and approaches to communication and collaboration between scientists and local residents vary greatly both across the North and across disciplines. 
Acknowledging the complexity of the various structures, rules, opportunities, and constraints across the North, we have strived in our portrait of Nunavut to provide one part of the bigger picture, with a special focus on cases from natural science. We hope that our detailed story from Nunavut illuminates some core themes that define community-researcher relationships here as potential factors to consider in other regions.

A variety of factors make Canada's newest territory a good setting in which to examine the dynamics of sciencecommunity relationships. The majority ( $85 \%$ ) of Nunavut's 30000 inhabitants are Inuit, who live in 26 remote communities. Like all research, natural science projects in Nunavut are subject to review and licensing under the Scientists Act (a territorial legislation dating from 1978; GNWT, 2006). Research must also undergo screening for potential impact on land use and the environment by regulatory bodies established under the Nunavut Land Claims Agreement (1993), by federal departments, and by regional Inuit associations. The Nunavut region has attracted natural scientists since the first International Polar Year in the 1880 s, and a legacy of dedicated field research infrastructure from the 1950s (e.g., at Resolute and Eureka) continues to support scientists from around the globe each year. The demand for this and other research infrastructure in Nunavut will increase dramatically during the next IPY (2007-09). Local communities will feel the impact as well, as Nunavut is expected to host more IPY projects than any other Canadian jurisdiction.

In terms of the number of projects, the natural sciences make up the majority of research conducted in Nunavut. Of the approximately 120 licenses issued annually under the Scientists Act, on average $60 \%$ are for natural science projects, $30 \%$ for social science projects, and $10 \%$ for medical health research (NRI, 2005a). However, the total scope of natural science research activities in Nunavut is in fact much greater when one includes geoscience in the form of mineral prospecting and exploration activities, which are expanding rapidly in the territory. In 2005, for example, 1136 prospecting permits were issued for Nunavut, and investment in mineral exploration there totaled more than 200 million dollars (INAC, 2005).

Though natural science projects make up the majority of research activity in Nunavut, opportunities for local involvement in those projects have historically been few. A 1989 study by the Northern Heritage Society in Yellowknife examined local employment generated in 1988 by scientific research in the Northwest Territories (including what is now Nunavut). It found that northern involvement in field research projects was highest in the social sciences, where Northerners filled $93 \%$ of jobs, as opposed to $40 \%$ in the biological sciences and $10 \%$ in the physical sciences. Only $7 \%$ of jobs in the social sciences required post-secondary training, as opposed to $60 \%$ in the biological sciences and over $80 \%$ in the physical sciences (Gorham and Spalding, 1989). Northern communities and researchers alike have also perceived there to be fewer opportunities for local input to the design of research for natural sciences than for fields of study such as archaeology, wildlife ecology, and human health studies, which are tied to an extensive and increasingly well documented body of local knowledge.

Despite low levels of involvement in the past, Nunavummiut recognize that natural science has played an important role in improving the well-being of communities, and there is no questioning the continued relevance of science to northern needs and interests. Insights stemming from natural science have led directly to practical, often revolutionary, applications that have greatly improved the quality of life in the North. Obvious examples include advances in navigation and telecommunications like Global Positioning Systems (GPS) and satellite phones; identification and mapping of sources of mineral wealth, e.g., with geological mapping radar; improved forecasting of weather and ice conditions, e.g., through remote sensing; and detection and remediation of contaminated sites.

Today, many Inuit regard natural science applications and the knowledge and advice of scientists as essential tools for advancing their knowledge about important phenomena, generating wealth, and safeguarding community health and well-being. Inuit communities and agencies increasingly call upon scientists to help them develop resource and environmental management plans; to conduct air, soil, snow, and water quality testing; and to help assess and explain new or unusual phenomena, such as pollution and climate change. Nunavut communities also recognize natural science projects as a potential source of local employment and income and as an avenue for community members, especially the young, to receive technical training and scientific fieldwork experience.

At the same time, many Inuit also express a desire for more influence in defining science and research needs and in determining how studies in their homeland are designed, conducted, and communicated. Inuit have called for greater access to project funding, as well as dedicated infrastructure and capacity to initiate, conduct, and manage research that addresses Inuit concerns and priorities. For example, Nunavut Elders and hunters have requested the establishment of a multi-purpose environmental research facility in Nunavut to monitor changes and perform rapid assessments of identified problems. Examples are screening for the dangerous trichinella parasite in walrus and polar bears and diagnosing of sooty deposits on snow (NTI, 2001; NRI, 2005b). Such a facility would be under Inuit control and guided by Inuit interests and prioritiesa top priority being to hasten the return of research results directly to community members. The role of the natural scientist would be that of technical advisor and facilitator, rather than manager, of Inuit-led projects. Nunavut residents and agencies increasingly believe that researchers and scientists have a responsibility to provide hands-on training and employment to Inuit youth that will foster their interest in long-term learning and encourage them to pursue careers in the sciences. 


\section{RESEARCH LICENSING IN NUNAVUT}

Research projects in Nunavut must be licensed, and the licensing process is an initial step in establishing sciencecommunity relationships. A hallmark of the process is the emphasis placed on community consultation. Indeed, from many Northerners' perspective, the sole purpose of the process is to provide a formal mechanism whereby local communities can evaluate and influence the scope of research that could affect them. Usually, community consultation entails ensuring that hunters and trappers' associations (HTAs), hamlet councils, and other authorities in potentially affected communities are aware of proposed research plans and have the opportunity to identify any potential harmful impacts. However, as this section and the case studies show, there is some confusion among researchers and communities, and a lack of clarity within the licensing policy itself, about what defines a licensable research project, how the impacts of research are best assessed and mitigated, and where decision-making powers should rest.

The chief instrument for science licensing in Nunavut is the Scientists Act. It applies to all research that is not covered under the territorial Wildlife Act, the regulations of the Nunavut Act that govern archaeological sites, the federal Fisheries Act, or national park regulations. The act empowers the Commissioner of Nunavut to appoint a territorial Science Advisor, who assumes the powers and duties vested in him or her under the act, principally the issuing of research licenses (Scientists Act Administration Regulations - Nunavut, R-174-96). This position has typically been assigned to the executive director of the Nunavut Research Institute (NRI), the agency responsible for administering the Scientists Act. The Science Advisor alone, in accordance with the act, has the ultimate authority to interpret the act and approve or reject any research license application.

At present, the Science Advisor defines licensable research as "baseline environmental studies, traditional knowledge, or socioeconomic studies," as well as all health projects not conducted by the Government of Nunavut (M. Thomas, pers. comm. 2006). The Science Advisor has also set some exceptions, such as mineral prospecting and exploration activities. Prospecting permits do not need research licenses unless the Science Advisor believes that the project might become economically viable. In that case, baseline environmental or socioeconomic studies are needed, which would require a research license (M. Thomas, pers. comm. 2006). Such prospecting projects are few; on average, not more than five are licensed each year (M. Thomas, pers. comm. 2006). Studies conducted by the Government of Nunavut (GN) are also not licensed, since their own guidelines for responsible research oblige government researchers to consult communities. Other exempt projects include pre-university student research (e.g., high school science fair projects), market survey research, and most types of industrial product development (e.g., testing an instrument prototype) in which information is proprietary. No procedure for dealing with exemptions is set out in the act or accompanying regulations, and all licensing decisions are at the discretion of the Science Advisor.

In addition to the NRI license, natural science projects require screening by the Nunavut Impact Review Board (NIRB) for environmental impact, and review by the Nunavut Planning Commission (NPC) to assess conformity with regional land-use plans where they exist (e.g., in Kivalliq). Natural science research on Inuit-owned Lands must further be approved by the appropriate regional Inuit association, while projects on Crown lands require screening and land-use approval by Indian and Northern Affairs Canada (INAC) and projects in the national parks require a permit from Parks Canada. Some specific projects may be subject to other reviews, for example, studies of freshwater systems may require screening by the Nunavut Water Board.

The NRI license application process ensures that scientists obtain all the necessary permits and authorizations for their projects. Researchers must describe their proposed field activities, including features of the proposed field locations, potential impacts of the project on wildlife and the environment, and plans for site restoration. Proponents must also provide details on the involvement of Nunavut residents in the project to date and elaborate on potential opportunities for local jobs, contracts, and training in the project.

The NRI forwards the research license application and a plain-language summary to any other relevant authorities, who in turn review the project and provide comments to the NRI. Review agencies, including community authorities, recommend in writing that the NRI accept or reject the application, identifying any terms and conditions they want attached to the research license. The Nunavut Science Advisor then informs the applicant of the reviewer recommendations and discusses how and to what extent the researcher can and should address local concerns. Rather than buffering the communication, however, the Science Advisor actively encourages researchers and communities to consult each other directly and early in the research process, to identify sources of potential conflict, and to negotiate an appropriate compromise. The Science Advisor decides whether community review recommendations warrant rejection of a license application and whether requested terms may be attached to the project license. However, conditions stipulated by regulatory institutions established under the Nunavut Land Claims Agreement (NLCA), such as the Nunavut Impact Review Board, must be applied to research licenses: that is, the NLCA takes precedence over existing legislation, including the Scientists Act.

Under the Scientists Act, researchers seeking a new license must submit to the NRI the annual summary reports from any licensed research done in previous years, as well as final reports on those projects already completed. The NRI does not have the resources to monitor and 
enforce licensed research activities; however, NRI-licensed research camps on Inuit-owned and Crown lands are subject to inspection by land-use authorities (i.e., INAC for Crown lands and the regional Inuit associations for Inuit owned lands). NRI staff members sometimes participate in these inspections, which enables them to assess compliance with NRI license conditions. According to the Scientists Act, researchers who breach the terms and conditions of the license or conduct unlicensed research in Nunavut are liable, on summary conviction, to a $\$ 1000$ fine or a prison term of up to six months, or both (R.S.N.W.T. 1988, c-S.4 (7)). These penalties have never been applied.

As noted, the Nunavut licensing process sets part of the stage for researcher-community relationships. In addition, the NRI and most Canadian universities expect all researchers to adhere to sets of general guidelines for responsible and ethical conduct. Many guidelines have been issued by multiple agencies (e.g., NRI and ITC, 1998; CYFN, 2000; NRI, 2000; ACUNS, 2003; WHO and CINE, 2003; ARCUS, 2004; ARI, 2004; NCP, 2004). While these guidelines are useful for general advice, in many instances they are unclear about issues like responsibility and accountability and about the application of the guidelines to natural science research (Korsmo and Graham, 2002). For example, is it the researcher who is entirely responsible for designing and facilitating community participation? Why do the guidelines differ with respect to appropriate levels of participation? Which principles of conduct apply to natural science research, and which do not?

Ultimately, each project (and each community) has its own story to tell about research-community relationships, and all disciplines have had successes and failures. In the last decade, as a result of changing attitudes, regulations, and methodology, and an increase in multidisciplinary projects, natural science researchers have interacted and worked with communities more than ever before. Unlike social scientists, they usually have little training in the theory, methods, and practices of participatory research, and little time to spend immersed in communities. Though such training and experience do not guarantee successful community relationships (indeed many social science projects have had poor community relations), their lack places natural science researchers in a unique position in northern research today when it comes to interactions with local communities. Their experiences provide valuable lessons for all who wish to work in an Arctic that is rapidly changing its views on research.

\section{CASE STUDIES}

To provide more specific examples of the challenges and opportunities that arise in science-community relationships at both project and policy levels, we present three case studies of licensed research projects that were conducted in Nunavut at different times since the early 1990s. We compiled the case studies by researching NRI reports and collecting documen- tation (held at the NRI) from both communities and researchers who were involved in the projects at the time. We have done our best to remove or disguise information that might identify individuals, communities, or organizations, as it is the experiences we are concerned with, and not who or where. Though each case is unique, overall the experiences represent some situations that have commonly occurred during several decades of projects conducted in what is now Nunavut.

The first two case studies describe some problems that can arise in research projects and specifically natural science projects. In both cases, neither the researchers nor the communities were satisfied with the outcome of consultations and negotiations, and the research projects ultimately did not continue. The third case study illustrates a successful science-community relationship that evolved from collaboration at the project implementation stage and continues to run successfully in Nunavut today.

These three cases lay the foundation for our discussion of common themes in the research process and developing best practices in research-community communication and partnerships.

\section{Case Study 1}

For two years, this natural science project was conducted at a seasonal camp located approximately $150 \mathrm{~km}$ from the nearest community. The camp staff was never more than six people, and the scientific equipment used was typical and basic, including ice augers, sediment core samplers, skidoos, a generator, and a four-wheeler. The use of fuel and hazardous material was very limited. No permanent structures were erected at the site, and all sampling and scientific research was at a relatively small scale. Initial consultations with the community revealed concerns about potential environmental impact on local lakes, but residents said they did not frequent the study area for traditional or other use and told the researchers they would be unlikely to meet local people out at the camp location. The project did not hire local help for fieldwork, though a university student interviewed some community members to ascertain local knowledge of the study area and the research topic.

During the project's third year, upon license renewal, the hamlet council wrote a letter to the NRI expressing concern over the conduct and impact of the research. The NRI responded, but requested a clearer demonstration of the existing or potential negative impacts of the project. The community council replied that if the researcher were to come to the community to consult about the project before fieldwork began in that year, as they had previously requested, then they could show the impacts clearly. The community looked forward to a chance to speak with the researcher and asked the NRI to support the community in its concerns.

The NRI helped to coordinate the researcher's visit to the community and paid for these travel costs. Meeting with the appropriate leaders and community organizations, the 
researcher presented an overview of the project and the rationale for site selection. During the meetings, the community raised several questions and concerns. The first was potential disturbance of fish in nearby lakes where the community fished. The researcher reiterated the reasons for choosing the site and noted that the small-scale research activity would not result in any environmental damage. Another concern was that the project would leave garbage or other permanent structures on the land. The researcher assured the community that all research structures, equipment, and wastes would be removed from the site, noting that on previous visits, project personnel had mapped a number of barrels on the land and applied to the Polar Continental Shelf Project for their potential removal. Next, the community asked if the researcher would hire community members and inquired about what benefits, specifically economic benefits, the community would see from the project. Since fieldwork was to commence in only a few weeks and resources had already been allocated, the researcher said it was too late to hire local residents for that year, but indicated this might be possible in the future. The researcher invited community members to visit and observe the fieldwork at the camp, where they would receive shelter and food during their stay; explained the broader impacts of the research for understanding the Arctic environment; and offered to provide data for community use. In relation to economic benefits, some community members also suspected that the researcher was engaged in unauthorized mineral exploration under the guise of research. The researcher assured the community their concerns were unfounded, explaining that prospecting was not an interest, nor was the research team trained in prospecting. Last, the community asked why the researcher had still carried out the project over the last two years despite their early and ongoing concerns and objections. Acknowledging that concerns had arisen at the project outset, the researcher indicated unawareness that they were so strong, noting that similar research had been carried out elsewhere in Nunavut where nearby communities were supportive.

Ultimately, the community did not support the research project and made it clear to the NRI and regional authorities that the research was not welcome. As a compromise, the researcher proposed to the NRI to complete the current year's research project, since plans were well underway, but to cancel research planned for subsequent years unless community support could be obtained. A license was issued, and the third season of fieldwork was carried out. The community never responded to the researcher's compromise proposal, though in correspondence with territorial and regional groups they made it clear that they did not approve of the fieldwork that year or any work at the project site at any time. The community cited the sensitive nature of the area, how surrounding lands and waterways are connected, local use of the specific and surrounding areas, and their concerns about possible impacts on fish and wildlife. They also noted their disappointment in the fact that authorities responsible for permitting the research activity (namely the relevant university and the NRI) did not support their position in the matter. They expressed their desire to be more extensively involved in the research licensing process for future studies and in particular, to have the right to decide what research would take place on their land.

For the researcher, there was disappointment and confusion. The researcher noted that concerns in the third year of the project came from a new hamlet council that apparently had no record of previous council decisions and communication. The research project did not return after the third season and moved to another location in Nunavut.

\section{Case Study 2}

The second case involves a field course for university credit, during which researchers and students traveled the land and conducted a variety of natural science field surveys, mapping, sampling, and observation. The research course ran for several seasons, using an area that a local community relied on for pre-existing tourism operations. Over those years, local community and business interests repeatedly complained about the course to territorial government authorities, land-claim agencies, and the NRI. Despite the protests, of which the researcher was aware, research licenses were still issued and the project continued.

Chief among local concerns over the field course was that it unfairly competed with local outfitting and tourism activities that took place simultaneously in the same areas. Community members perceived that the majority of the course participants were there for an Arctic experience, not necessarily to conduct scientific research; the proponent was engaging in for-profit, commercial tourist activities that required an outfitter's license. The community also stated that the types of travel and camping engaged in by the course participants were unsafe and detracted from the experience of other tourists in the area (those led by local outfitters). By not coordinating with local outfitters, the researchers were compromising the experience of other tourists, since local guides time their trips so that groups of tourists are unlikely to see each other, to allow everyone an equal opportunity for quiet time on the land. Moreover, the community felt that by not using the services of local outfitters to conduct the field trips, the research course was depriving local people of badly needed revenue and jobs. The local hunters and trappers' association (HTA) had suggested that the researcher find a different area where project activities would not interfere with existing businesses. The researcher claimed to have made repeated attempts over the years to establish good working relationships with the local business and community authorities, including efforts to seek funding for local Inuit to visit with the student participants, but with limited success.

Questions over whether university field courses required outfitter's licenses in order to operate were brought to the territorial Justice Department, prompting the department to seek a legal opinion on the matter. Legal counsel 
found that universities and colleges engaged in the delivery of recognized credit courses or licensed scientific research did not require an outfitter's license.

During the last year of the project, the regional Inuit association refused to issue a license for access to Inuitowned lands (as required by the NRI research licensing process). The regional Inuit association cannot grant a license without the approval of the local Community Lands and Resources Committee-in this case the local HTA, which did not give approval. However, the association did inform the researcher of the public's right to access and use the land under the Nunavut Land Claims Agreement. Under the land claim, everyone has a right of access to cross Inuit-owned lands for personal or casual travel, for example, to go to or from a place of recreation.

The proposed activities were screened and approved by the Nunavut Impact Review Board. The NIRB recommended that the researcher consult with local outfitters and coordinate a schedule that would allow all trips to be run independently and ensure that the research trips did not disrupt the community's guided tours. In an effort to address community concerns, the researcher decided to move the field trips to an area used less intensively by the local outfitting business. The NIRB approval was amended for the new location; however, the community again issued a notice stating its continued opposition to the project. The NRI granted a research license for the revised location. With that authority, and with the rights provided under the Nunavut Land Claims Agreement, the research course was carried out, but that was the last year the course was offered.

\section{Case Study 3}

The third case involves an ongoing, long-term physical science study being carried out at various locations in Nunavut. As in the first case, research activities are small in scale with minimal environmental impact. The field team consists of two to four people who spend less than 100 person days at each site collecting data. Research equipment is basic and low-impact, comprising a hand drill for sampling, a ski-doo, a small tent, and a wooden hut, with occasional aircraft support. The use of fuel and hazardous material on site is limited.

The project has received Nunavut research licenses in several years, and the study has not encountered community opposition. The lead researcher has developed a long-term personal relationship with members of a community near one of the study sites. Before embarking on each field visit, the researcher spends an extra couple of days in the nearby community to visit informally with local authorities. The researcher's experience in this community is that face-to face communication is much more productive than correspondence by fax, phone, or mail. The researcher also visits the school at this time to give presentations and posters related to the research goals, methods, and results, and local adults occasionally attend the school talks. In addition, a "twinning program," which involves a collaborative scientific sampling project, has been established between the local school and a school from the researcher's home province. The researcher analyzes samples from both locations and discusses the results with students at both schools during classroom activities. Continued support and enthusiasm from the local school principal and teachers have been crucial in ensuring the success of these efforts to involve local students.

Although bringing students and community members to visit the main research location was originally identified as a key objective, this has proved logistically impractical. Instead, the researcher has established a "proxy project" at another, more accessible location. Here, the research team can provide students and other community residents with first-hand demonstrations of the field research techniques and instruments being used at the main research site. Community members have been hired in some years to assist with camp setup and decommissioning. The researcher has also provided information about observations made at the main research location to inform community members about various conditions in the area and help them identify safe travel routes.

\section{DISCUSSION}

The case studies illuminate some of the core themes driving community-researcher relationships in Nunavut today and provide some important points for consideration in any region. Three major themes underlying the problems and challenges emerge: economic impacts and benefits, power and authority, and research methodology and design. Each case has elements of each theme, though in different ways, to different extents, and with both positive and negative outcomes. Here we examine each theme, using examples from the case studies, and begin to build suggestions to improve community-researcher relationships, in particular for natural science projects.

\section{Economic Impacts and Benefits}

Local authorities in Nunavut have consistently requested that scientific research projects provide some form of economic benefit to local communities (NRI, 1996, 1997, 2005b). Increasingly, communities in which local opportunities to generate private-sector income are limited view research as a source of potential employment and revenue. Local authorities frequently request that researchers hire local labor or use the services of local contractors to the fullest extent possible. While they are not designed as job creation schemes, natural science research projects are often in a position to hire community members, particularly to help plan, implement, and manage research and field logistics (e.g., land travel, camp setup and take-down, fuel caching, maintenance and re-supply, sampling, sample preparation and transport, equipment monitoring). For example, 
researchers may be asked to rent local boats or snow machines for transportation to and from research locations, rather than using helicopters or other outside means of transport. Local people may also seek employment as field guides, cooks, interpreters, bear monitors, and research assistants.

The researchers in Cases 1 and 2 both ran into conflict with communities over local perceptions that their research was not providing sufficient economic benefit. In Case 1, the community was disappointed that hiring local assistants was not part of project planning. Local people were not hired to work at the camp, nor were they employed to conduct the traditional knowledge study. The face-to-face meeting between the community and the researcher helped to bring these concerns to light and gave the researcher an opportunity to consider local people in future planning, but it was too late to modify the project sufficiently or to build the rapport necessary to alleviate community concerns. The negotiations that took place during the meeting highlight the importance and benefit of early, in-person consultation with communities during research planning.

In Case 1, the issue of hidden agendas and suspected ties of the research to mineral exploration were particularly surprising and difficult for the researcher. Local mistrust of the research motives was pervasive, though not supported by empirical evidence, and the community, despite reassurances from the researcher and the NRI, held onto this distrust. Perhaps some suspicion is understandable, given the secretive and highly competitive nature of mineral prospecting activities, along with the rapid expansion of such activities in Nunavut and the researcher's initial reluctance to bring a local resident along on the field project to monitor activities. This problem may also speak to deeper fears that scientific research can be used as a tool to restrict Inuit access to their traditional lands and wildlife and keep them from economic benefits. The researchers might have avoided misunderstandings over project goals and activities and achieved more meaningful local participation if they had communicated earlier and more frequently with the community about the project.

In Case 3, the community has come to trust the research team since community members were brought physically to the site early on to view research activities firsthand. This, as well as ongoing demonstrations of research techniques and presentations of results, may have helped convince any skeptical community members that the researcher was conducting legitimate work in accordance with the stated goals.

Case 3 is also an example of research providing some economic benefit to a community, and it is important to note that a number of natural science research projects do indeed hire local help. In the example of Case 3, this includes camp setup and take-down and other field logistics. Cases 1 and 2 did not hire locally, and at the core of the difficulties faced in Case 2 was the perception that the research project not only did not offer economic opportunity to local people, but took away existing and potential opportunities. Had the researcher made efforts to partner with a local outfitter, using its services even partially, and tried to time the project so as to avoid tension with other groups touring the area, much of the animosity could have been averted. Again, better communication and consultation could have played a major role in improving the negotiation of this research effort (see Methods and Research Design below).

The amount of project money spent in communities is constrained by a number of factors. First, researchers may assume or perceive that local people would not be interested in or have skills to contribute to highly specialized and technical projects. Language and cultural barriers (both real and perceived) impede communication between researchers and communities, especially on technical matters related to science. As well, natural scientists do not necessarily have experience or training in public engagement methods or in cross-cultural communication to help them establish the necessary rapport. Second, although local people might make able research assistants, funding agencies and universities can pressure researchers to support and train undergraduate or graduate students as research assistants. Third, natural science field campaigns often take place during times of peak seasonal harvesting and camping activities when many Inuit are enjoying time on the land with family and are not available or willing to join scientific field camps for extended periods of time. Fourth, researchers are often unaware of the supplies, amenities, or experienced personnel that are available in communities and can be drawn upon to assist with fieldwork. Sometimes researchers do not make the effort to seek out this information, but it can also be difficult to access. Especially on the first trip, researchers are likely to bring all of the provisions they need as opposed to risking not finding an item available in local communities.

A difficult question is to what extent research projects should provide local employment and training. In many instances, relying on local labs and services saves science projects considerable money and results in better study designs. Training exchanges can also improve research, providing valuable education to researchers as well as community members (e.g., Table 1). However, natural science research is ultimately designed not to generate local employment and revenue, but rather to advance scientific knowledge. In allocating scarce project resources, the need to produce quality science will almost always override the need to provide local employment and training. Scientists have usually considered the public to be outside their area of expertise and people to be "overburden" (Bielawski, 1992). Some scientists have perceived the local desire for employment benefits from research as compromising quality assurance and quality control. In the case of wildlife research, for example, local hunters and trappers' organizations may request that a different local person participate in subsequent years of a project, as a means to ensure that as many people as possible gain 
employment. However, using new field personnel may increase training costs and introduce observer bias, as individuals differ in their ability to apply field data collection protocols (Shirley, 2002).

\section{Power and Authority}

Issues of power surround the interactions of indigenous people, their knowledge, and science (Colorado, 1988; Agrawal, 1995; Purcell, 1998). In all regions of the North, power relationships between indigenous communities and scientists are played out in various contexts, from environmental management (Ellis, 2005) to land claims (Dybbroe, 1999). The research licensing consultation process under the Scientists Act has emerged as an important forum for negotiating power relationships between communities, scientists, and regulatory agencies in Nunavut. But communities and researchers alike are often unclear about what it entails, and in particular, about the role community agencies play in the license application review and approval process. Local reviewer feedback helps to inform the Science Advisor about community concerns and potential risks and benefits of each proposed project, but the final decision is at the sole discretion of the Science Advisor. Local reviewers have only the power to recommend: they cannot make the decision to approve or reject a license application or set the terms and conditions included in the license. Community authorities often do not understand, or agree, with this process, as was seen in Case 1: community members placed great emphasis on their right (or lack thereof) to refuse any research project or activity on their land. Correspondence from both the researcher and the community shows that the community did not clearly understand that the territory, not the community, has final authority to approve or deny a research license.

There is also confusion as to the types of local concerns that might warrant denial of a research license and the conditions that may be attached to licenses. The Scientists Act suggests that research license applications may only be denied when the Science Advisor determines that the research will result in negative social or environmental impacts. The failure of a project to provide some desired level of socioeconomic benefits is not sufficient grounds for withholding a license, according to the current interpretation of the act. Licenses may be withheld only when the Science Advisor decides there is documented, legally defensible evidence that the proposed project would have negative effects on the well-being of people or the environment. The environmental concerns the community cited in Case 1 were deemed insufficiently described or proven to warrant a refusal. It was never made clear in Case 1, nor does the act make it clear for any case, how exactly local concerns need to be worded or proven in order to satisfy the Science Advisor that a license should not be issued.

Though clear guidelines are not in place, the NRI makes every effort during the licensing process to facilitate communication between researchers and communities aimed at resolving disputes and reaching a mutually acceptable compromise over proposed research. We saw this in Case 1, when the NRI arranged for the researcher to travel to the community for further consultation. However, it is important to note that in more than a decade since the NRI began issuing research licenses, no research application has ever been rejected (M. Thomas, pers. comm. 2006). Applicants have been compelled to make major changes in their project plans to address concerns raised by the NRI, communities, and other review agencies, and some researchers have withdrawn applications because of NRI concerns, but no application has ever been denied or revoked. There are a number of possible reasons. It may be that the licensing process has been effective in facilitating compromise between communities and researchers, and that research has been flexible enough to accommodate community concerns. Another explanation may be that community authorities have been unable, through lack of evidence or procedure, to convince the NRI or other authorities that a proposed activity should not be licensed because of anticipated negative local impacts.

Power is a problem not only at the institutional level, but also in local communities. Local politics and struggles for power can also cause problems for research relationships. For example in Case 1, the composition of local administration changed after the first two years of the research project. During the third year, the new town council in power apparently had no record of the researcher's previous efforts to consult with the community and clear up issues that had been identified. The new council may have had different views of research, a different governing style, or perhaps more time to review the project and understand its potential impacts. There was no system in place for the research project to have continuity under a new administration. Local power struggles can complicate the consultation process in other ways, for example, if one local authority (e.g., HTA) supports a license application while another local authority (hamlet council) rejects it. In such cases, it may not be possible for a researcher to garner support for a proposal from all members of a community. In most instances, the hamlet council is recognized as the primary local authority for licensing matters; however, discretion rests with the Science Advisor to determine which (if any) local recommendations are to be upheld in a licensing decision. Ultimately, under an NRI-approved license, the situation becomes a personal choice by the researcher to continue despite community opposition or find a new location for the project where local support might be found. In both Cases 1 and 2, hamlet councils and other local organizations did not approve of the project, though licenses were still granted. In Case 1, the researcher chose to move the project to a place where there was support. In Case 2, however, the researcher chose to stay for several more years despite strong resistance from the community. 
TABLE 1. Examples of skills that can be exchanged between natural scientists and community members. Training exchanges not only improve skills, but can also help establish good community-researcher relationships and create mutual trust and understanding.

\begin{tabular}{|c|c|c|}
\hline Discipline Examples & Researcher to Community & Community to Researcher \\
\hline Astrophysics, Astronomy & $\begin{array}{l}\text { - telescope and theodolite use } \\
\text { - star maps } \\
\text { - lectures and demos to schools on planetary science }\end{array}$ & $\begin{array}{l}\text { - traditional understanding and personal observation of stars } \\
\text { and atmospheric phenomena } \\
\text { - traditional navigation techniques based on stars }\end{array}$ \\
\hline Geology & $\begin{array}{l}\text { - survey equipment and GPS } \\
\text { - field techniques such as sample collection, identification } \\
\text { (prospecting), and storage } \\
\text { - lectures on topics such as northern geology, community } \\
\text { geology, uplift, terrain sensitivity to changing conditions, etc. }\end{array}$ & $\begin{array}{l}\text { - mapping and guiding; locating sought-after rock types } \\
\text { - field assistance in transport, sampling, camp setup and } \\
\text { maintenance } \\
\text { - maps of various rock types based on local knowledge (e.g., } \\
\text { carvers are especially aware of deposits useful for art) }\end{array}$ \\
\hline Fresh Water Research & $\begin{array}{l}\text { - equipment and training to measure and assess water chemistry, } \\
\text { depth, and flow rates } \\
\text { - methods for rapid visual assessment of streams, lake } \\
\text { morphology, and riparian habitat characteristics } \\
\text { - information and equipment for monitoring water quality and } \\
\text { levels } \\
\text { - knowledge about associated vegetation, animal activity, } \\
\text { permafrost, etc. }\end{array}$ & $\begin{array}{l}\text { - location of water supplies, areas of contamination or } \\
\text { concern } \\
\text { - information on and monitoring of water quality and levels, } \\
\text { lake ice, fish, etc. } \\
\text { - knowledge about associated vegetation, animal activity, } \\
\text { permafrost, etc. } \\
\text { - insights on timing of freeze-up and breakup; thickness } \\
\text { trends of lake ice } \\
\text { - hazards (thin ice, shallow areas) and boating routes }\end{array}$ \\
\hline Military Science & $\begin{array}{l}\text { - leadership courses } \\
\text { - orienteering and navigation } \\
\text { - training on various equipment such as new guns, GPS systems }\end{array}$ & $\begin{array}{l}\text { - arctic survival skills } \\
\text { - navigation skills and knowledge of specific safe travel } \\
\text { routes and camping areas }\end{array}$ \\
\hline Glaciology & $\begin{array}{l}\text { - glacier travel } \\
\text { - using remote sensing, air photos, maps, GIS, remote/ } \\
\text { automated weather stations, for tracking glacier activity } \\
\text { - glacier change detection and rates }\end{array}$ & $\begin{array}{l}\text { - glacier travel } \\
\text { - identification and inventory of glaciers; glacier history } \\
\text { (e.g., changes in position of glacial margins or in rate and } \\
\text { extent of melt) } \\
\text { - ground truthing of remote sensing information } \\
\text { - insights on ecological consequences of changes in glaciers }\end{array}$ \\
\hline Oceanography & $\begin{array}{l}\text { - ocean travel and safety } \\
\text { - access to scientific tools (e.g., satellite maps) for observing } \\
\text { and assessing sea ice conditions and change } \\
\text { - understanding of broad scale current and wind patterns, } \\
\text { characteristics and changes } \\
\text { - identification of sea biota, e.g., sharing knowledge of deep sea } \\
\text { - tours of ships and other sea vessels, as well as basic training } \\
\text { on ship equipment }\end{array}$ & $\begin{array}{l}\text { - ocean travel and safety } \\
\text { - currents, tides and other unique physical characteristics of } \\
\text { local marine systems } \\
\text { - traditional means for observing and assessing sea ice and } \\
\text { sea water quality and changes } \\
\text { - identification and monitoring of marine biota } \\
\text { - identification and monitoring of sites of coastal erosion } \\
\text { and isostatic rebound } \\
\text { - understanding of patterns, changes, and impacts of wind } \\
\text { and wave activity, } \\
\text { - local history and significance of storm surges and their } \\
\text { impact }\end{array}$ \\
\hline
\end{tabular}

\section{Methods and Research Design}

At the project level, some of the conflicts surrounding economic impacts and power can be resolved or prevented through careful research design and methods, especially when communities are involved meaningfully in the earliest stages in the development of a project. Early (and ideally inperson) community consultation, regular research reports, and use of local experience and resources are key steps to building relationships and trust between the researcher and community.

All of our case studies had problems and tensions between researchers and community that were related to project methods. For example, in Case 1, the community was concerned that scientific activities would damage the environment and local fish. Part of the problem might have been that residents did not fully understand project methods. Although the researcher spent time meeting with community leaders to explain the project and had included a written summary of methods with the research license application, community members were still unclear about project goals and activities. More frequent and creative reporting could have helped keep community members informed over the first two years of the project, thus preventing the confusion and resentment arising from their suspicion that the researcher had other motives. Visual means, such as photos or videos, to explain project methods would have been most useful, and especially site visits, so community members could see the scientific activities for themselves.

Case 2 offers several other insights. The first, again, is the value of early consultation. If this had occurred, both the researcher and community might have identified problems, such as the local outfitters' perceiving the project as competition to local tourism, and the researcher might have understood locally important times for tours. Early consultation would also have revealed local skills and resources, in this case Inuit guides, equipment, and local 
transportation. The case also reveals some finer points, such as local perceptions of the ways in which a project could detract from or interfere with community livelihoods, both directly and indirectly. For example, local people considered vehicles and tents of the type and colour the field course was using to be not only a safety problem, but an aesthetic one.

Many of the challenges faced in community-researcher interactions, like those in the case studies, could be alleviated by making local consultation, engagement, and, communication integral parts of research design. As a prerequisite of project success, research team members should be assigned the explicit task of planning and coordinating local interaction and activities, and existing personnel and resources should be deployed creatively for this purpose. For example, projects that fund student assistants might consider putting them in charge of coordinating community relations activities. Their tasks could include scheduling and conducting early consultations, reporting regularly to communities, managing researchercommunity training exchanges, hiring and training local field assistants, speaking at schools, and developing plain language summaries and a project website. Such a system would not only assign responsibility for designing and executing efforts to work with communities, but also train young researchers to work with local people, thus helping to prepare the next generation of northern researchers to work with communities. Giving young researchers the opportunity to engage in collaborative work will make them more likely to develop not only the specific language and skills of their science, but also the ability and practice of making their field understandable to a broader audience.

Lastly, we want to raise an important aspect of research that is sometimes overlooked: personal friendships between community members and researchers. Something that cannot be designed into a project, personal relationships are still a large part of the foundation for supported and successful research projects and the key to needed acceptance and trust in communities (Fienup-Riordan, 1999; Fox, 2002). These relationships form naturally through time spent with people and through participation in local activities. For natural scientists, a willingness to contribute extra time and resources to engage in community life and collaborate with community members is a good start to gaining support and sparking local collaborations. Fienup-Riordan (1999:20) explains in a statement that rings true throughout the North:

Over and over again, villagers' statements reflect their view that how things are done [in research] in their area is as important as what is accomplished. Sharing management of research projects is as important as any specific research policy decided on or results obtained. Researchers and those who fund them need to ask if what they learn from projects planned outside of the community is worth the cost in terms of resentment and resistance on the local level. Conversely, research projects perceived as responsive to local concerns in all stages-planning, implementation, and review — stand a much greater chance of eliciting community cooperation and support.

The personal decisions made by researchers in Cases 1 and 2 help illustrate an important aspect of this. The community that voiced concerns about the research in Case 1 ultimately respected the researcher's decision to finish up the current research season and then move locations, whereas in Case 2, local resentment and protest grew even more intense when the researcher chose to stay on and continue the project.

Of course, researchers are not likely to gain the trust and respect of every community member. Some Nunavut residents harbour deep feelings of suspicion and resentment toward research that stem from their experience with scientific projects in the past (even decades ago) that were perceived to have caused local harm. Personalities can clash as well, and not every person is going to agree with every project. But researchers can only gain from employing project methods that work to build trust and rapport. Trust is crucial. The problems in the first two cases flowed from distrust of research motives. In Case 3, trust was obtained because of constant interaction with the community and a willingness to share information and resources.

\section{CONCLUSION}

Recent decades have seen profound social, political, and legal changes in the North (Nuttall and Callaghan, 2000). In Nunavut, the formalization of land-claim agreements has established a new institutional and regulatory regime for research, which in turn has raised expectations and questions about the extent to which research projects need to engage with local communities and provide local socioeconomic benefit, as well as the types of impacts of research that are acceptable. The institutional context has also highlighted uncertainty about the role of communities and their authority to determine whether and how research projects should proceed-uncertainty that has sometimes led to conflict.

Changing methodologies and paradigms have contributed to the new research context for Nunavut. Research today is planned more and more using "participatory" approaches, and traditional knowledge is often included as a component in data collection or decision-making processes. But the benefits of these approaches and the extent to which these changes have resulted in real, meaningful input from Inuit are debatable (e.g., Nadasdy, 1999; Ellis, 2005). It seems that so far, neither policy changes nor methodology changes have resulted in real empowerment of communities in Nunavut, although such empowerment is often stated to be the goal of change in the first place.

The case studies of natural science projects presented in this paper do help suggest a way forward. First, despite the challenges and frustrations that can occur on both sides, it 
is essential to keep up communication between researchers and communities. This is the only way to reveal problems, create solutions, and negotiate actions that work for all parties. Next, creative methods do help to improve working relationships and play a key role in researchcommunity collaboration. At the same time, we need to move beyond rewriting research guidelines and look at the way the research process itself is constructed. Both communities and researchers need more than guidelines: they need the capacity to work better together. Specifically, there is a need for research licensing bodies to lead the way in facilitating better communication and information sharing between researchers and communities and better tracking of research activities. Decision making on both sides would also benefit from a better understanding of rights related to research. Funding agencies need to understand the impact on both research projects and communities when they require projects to include local involvement and outreach, and they must commit sufficient funds for these activities.

The natural sciences will continue to play a key role in the future of northern research. Natural science and innovations related to environmental change, contaminants, energy alternatives, mineral resources, telecommunications, and housing options, among others, will also continue to have a great impact on northern policies and quality of life. The current emphasis on community involvement in research is only likely to strengthen in the coming years, and indeed we see the great emphasis placed on it for the upcoming International Polar Year 2007-09 (ICSU, 2004) and in major circumpolar research efforts like the Arctic Observing Network (NRC, 2006). Natural scientists are responding, but more effort is needed to train researchers, educate funding programs, mobilize institutions, and empower communities. The capacity of all stakeholders in northern research needs to be strengthened. We hope this paper has contributed to these efforts by addressing some of the unique aspects and considerations of linking communities with natural science research. We have offered some specific suggestions on how to move forward. Further practice and experience will undoubtedly provide new insights into the ongoing evolution of research partnerships at both project and policy levels.

\section{ACKNOWLEDGEMENTS}

This paper is the result of informal discussions we had at the 14th Inuit Studies Conference in Calgary, Alberta, 11-15 August 2004. We are grateful for conversations with Scot Nickels, Eric Loring, Gita Laidler, and Mary Ellen Thomas that helped to form this paper. We are grateful to Mary Ellen Thomas and the Nunavut Research Institute for help with researching NRI policies. Special thanks to the Nunavummiut who have worked with us on our own research projects over the years and to the three anonymous reviewers who provided us with valuable comments.

\section{REFERENCES}

ACUNS (ASSOCIATION OF CANADIAN UNIVERSITIES FOR NORTHERN STUDIES). 2003. Ethical principles for the conduct of research in the North. Ottawa: ACUNS.

AGRAWAL, A. 1995. Dismantling the divide between indigenous and scientific knowledge. Development and Change 26(3): 413-439.

ARCUS (ARCTIC RESEARCH CONSORTIUM OF THE UNITED STATES). 2004. Guidelines for improved cooperation between Arctic researchers and northern communities. Fairbanks: http://www.arcus.org/guidelines/document.html.

ARI (AURORA RESEARCH INSTITUTE). 2004. Doing research in the Northwest Territories: A guide for researchers. Inuvik: ARI, Aurora College.

BIELAWSKI, E. 1992. Inuit indigenous knowledge and science in the Arctic. Ottawa: Canadian Arctic Resources Committee. Northern Perspectives 20(1). http://www.carc.org/pubs/v20no1/ inuit.htm.

COLORADO, P. 1988. Bridging Native and Western science. Convergence 21(2 and 3):49-69.

CYFN (COUNCIL OF YUKON FIRST NATIONS). 2000. Traditional knowledge research guidelines: A guide for researchers in the Yukon. Whitehorse: CYFN.

DYBBROE, S. 1999. Researching knowledge: The terms and scope of a current debate. In: Sejersen, F., ed. Changes in the Circumpolar North: Culture, ethics, and self-determination. Keynotes Presented at the Third International Congress of Arctic Social Sciences. Topics in Arctic Social Sciences 3. Copenhagen: International Arctic Social Sciences Association (IASSA). 13-26.

ELLIS, S.C. 2005. Meaningful consideration? A review of traditional knowledge in environmental decision making. Arctic 58(1): $66-77$.

FIENUP-RIORDAN, A. 1999. Yaqulget Qaillun Pilartat (What the birds do): Yup'ik Eskimo understanding of geese and those who study them. Arctic 52(1):1-22.

FOX, S. 2002. These are things that are really happening: Inuit perspectives on the evidence and impacts of climate change in Nunavut. In: Krupnik, I., and Jolly, D., eds. The earth is faster now: Indigenous observations of Arctic environmental change. Fairbanks: ARCUS, in cooperation with the Arctic Studies Center, Smithsonian Institution. 12-53.

GNWT (GOVERNMENT OF THE NORTHWEST TERRITORIES). 2006. Scientists Act, R.S.N.W.T. 1988, c. S4. http://www.canlii.org/nt/laws/sta/s-4/20061114/whole.html.

GORHAM, V., and SPALDING, P. 1989. A survey of NWT scientific field research labour market. Yellowknife: Northern Heritage Society.

ICSU (INTERNATIONAL COUNCIL FOR SCIENCE). 2004. A framework for the International Polar Year 2007-2008. http:// www.icsu.org/1_icsuinscience/ENVI_Ipy_1.html.

INAC (INDIAN AND NORTHERN AFFAIRS CANADA). 2005. Nunavut: Mining Mineral Exploration and Geoscience, 2005. Ottawa: INAC.

KORSMO, F.L., and GRAHAM, A. 2002. Research in the North American North: Action and reaction. Arctic 55(4):319-328. 
NADASDY, P. 1999. The politics of TEK: Power and the "integration" of knowledge. Arctic Anthropology 36(1):1-18.

NCP (NORTHERN CONTAMINANTS PROGRAM). 2004. Northern Contaminants Program (NCP) operational management guide. Ottawa: NCP. http://www.ainc-inac.gc.ca/ncp/ opmgmgui_e.pdf.

NRC (NATIONAL RESEARCH COUNCIL). 2006. Toward an integrated Arctic observing network. Washington, D.C.: The National Academies Press.

NRI (NUNAVUT RESEARCH INSTITUTE). 1996. Nunavut research agenda: Research policy and priorities for NunavutBackground study and discussion document. Iqaluit: NRI.

- 1997. Nunavut research agenda: Research policy and priorities for Nunavut. Iqaluit: NRI.

- 2000. Scientific research licensing guidelines. Iqaluit: NRI. http://www.nunanet.com/ research/reslicensing3.htm.

- 2005a. Nunavut research licensing statistics. Unpubl. document available at NRI, P.O. Box 1720, Iqaluit, Nunavut $\mathrm{X} 0 \mathrm{~A} \mathrm{OHO}$.

- 2005b. Research needs survey: Nunavut survey results. Whitehorse: Canadian Climate Impacts and Adaptation Research Network.

NRI (NUNAVUT RESEARCH INSTITUTE) and ITC (INUIT TAPIRISAT OF CANADA). 1998. Negotiating research relationships: A guide for communities. Iqaluit: NRI and Ottawa: ITC (now ITK-Inuit Tapiriit Kanatami).

NTI (NUNAVUT TUNNGAVIK INCORPORATED). 2001. Elders Conference on Climate Change. Proceedings of a conference held on 29-31 March 2001 in Cambridge Bay, Nunavut.

NUNAVUT LAND CLAIMS AGREEMENT. 1993. An Agreement between the Inuit of the Nunavut Settlement Area and Her Majesty The Queen in Right of Canada. www.nucj.ca/library/ bar_ads_mat/Nunavut_Land_Claims_Agreeement.pdf.

NUTTALL, M., and CALLAGHAN, T.V., eds. 2000. The Arctic: Environment, people, policy. Amsterdam: Harwood Academic Publishers. 647 p.

PURCELL, T.W. 1998. Indigenous knowledge and applied anthropology: Questions of definition and direction. Human Organization 57(3):258-272.

SHIRLEY, J. 2002. Tracking change: An analysis of efforts to involve the Nunavut public in wildlife monitoring. MES Thesis, Dalhousie University, Halifax, Nova Scotia.

WHO (WORLD HEALTH ORGANIZATION) and CINE (CENTRE FOR INDIGENOUS PEOPLES' NUTRITION AND ENVIRONMENT). 2003. Indigenous peoples and participatory health research: Planning and management, preparing research agreements. Geneva: WHO and CINE. 